\title{
ANALYSIS OF EEG CHARACTERISTICS AND COHERENCE IN PATIENTS DIAGNOSED AS BORDERLINE PERSONALITY
}

\author{
Nada Pop-Jordanova ${ }^{1}$, Silvana Markovska-Simoska ${ }^{1}$, Maja Milovanovic ${ }^{2}$, Dusica Lecic-Tosevski ${ }^{2}$
}

\author{
${ }^{1}$ Macedonian Academy of Sciences and Arts, Skopje, North Macedonia \\ ${ }^{2}$ Institute for mental health, Belgrade, Serbia
}

Corresponding author: Nada Pop-Jordanova, Bul Krste Misirkov br.2, P.O.Box 428, 1000 Skopje, North Macedonia, e-mail: popjordanova.nadica@gmail.com

\section{ABSTRACT}

Borderline personality disorder is a clinically important psychiatric diagnosis that is distinct from major depressive, bipolar and posttraumatic stress disorders, despite the overlapping symptoms. The diagnosis is mainly clinical and must follow the DMS 5 (or ICD 10) characteristics.

The most common age at first presentation is in late adolescence, but the disorder frequently can be stay as misdiagnosed.

Our study is concerned to QEEG characteristics, as well as coherence in borderline patients compared with healthy group, matched by number, gender and age and selected randomly.

Our obtained results showed that electrophysiological characteristics for borderlines are fairly without statistical differences, except in low bands (delta and theta), which showed significantly lower frequencies and coherence compared to a healthy group.

Future research in this filed with more patients is highly recommended.

Keywords: coherence, borderline, electroencephalography.

\section{INTRODUCTION}

Borderline personality disorder (BPD) can be a difficult diagnosis, because of similarities to other psychiatric conditions, particularly with mood disorders. The prevalence is assumed to be about $1 \%$ in the general population, where women constitute more than $70 \%$ of the patients. The most common age at first presentation is in late adolescence, but the disorder can frequently be misdiagnosed [1].

In the history of psychiatry it was written that the term "borderline" was firstly described by the psychoanalyst Adolf Stern in 1938 to a group of patients, whose conditions worsened during therapy and who showed masochistic behaviour and psychic rigidity, indicating a protective mechanism against any perceived changes in the environment or within the individual.

The current criteria for borderline personality disorder, in the absence of biological markers, share problems with other psychiatric disorders, unclear delimitation, and a wide variety of combinations of symptoms. In a fifth revision of DSM [3] the follow- 
ing symptoms for borderline are cited, where more than 5 of them are needed for diagnosis:

- Frantic efforts to avoid real or imagined abandonment;

- A pattern of unstable and intense interpersonal relationships characterized by alternating between extremes of idealization and devaluation;

- Identity disturbance: markedly and persistently unstable self-image or sense of self;

- Impulsivity in at least two areas that are potentially self-damaging (e.g., spending money, sex, substance abuse, reckless driving, binge eating);

- Recurrent suicidal behaviour, gestures or threats, or self-mutilating behaviour;

- Affective instability due to a marked reactivity of mood (e.g., intense episodic dysphoria, irritability or anxiety usually lasting a few hours and only rarely more than a few days);

- Chronic feelings of emptiness;

- Inappropriate, intense anger or difficulty controlling anger (e.g., frequent displays of temper, constant anger, recurrent physical fights);

- Transient, stress-related paranoid ideation or severe dissociative symptoms.

In the practice, the impulsive symptoms of borderline personality disorder may be more recognizable, but they can still pose diagnostic challenges. Between $60 \%$ and $78 \%$ of patients with the disorder have shown suicidal behaviours, with more than $90 \%$ engaging in self-harm. However, there are 256 different combinations of symptoms that could be present, which make a remarkable challenge to the clinicians to make a diagnosis of borderline personality disorder [4-6].

If the diagnosis of borderline personality disorder is not made properly, an affected person may end up with several diagnoses of comorbid disorders, none of which responds to common treatments. Borderline personality disorder is mainly a clinical diagnosis, with no supporting laboratory or imaging tests. However, some additional examination, especially EEG and psychometric tests are frequently applied in practice. In this context the Diagnostic Interview for Borderlines - Revised [7] is a validated and frequently used tool that is generally considered "gold standard". It is a rule that the diagnosis must be clarified with the patients themselves and some information about the criteria, treatment and prognosis must be discussed together.

In a research especially, EEG as a powerful tool for the assessment of physiological specifics of the human brain was frequently used. In our longterm clinical practice, QEEG analysis, spectra power and ERP's analysis were included in the assessment of different psychiatric conditions. In this context, another parameter in the analysis, like EEG coherence, was included too.

Coherence represents the mathematical measure of degree of similarity of the EEG recorded at two sensors. It is an index of brain connectivity between the brain regions accessed by the chosen electrodes. High coherence represents a measure of strong connectivity and low coherence a measure of weak connectivity. EEG coherence is a useful tool for measuring changes in the neurological functioning, which are not detectable by simply measuring amplitude or power spectra.

Practically, coherence is a linear synchronization measure between two signals recorded at different locations. It is a statistical measure of the average agreement in phase difference, weighted by amplitude, between two signals measured over time, and is frequency specific. Coherence values range from 0 to 1 , with 1 meaning perfect agreement in phase difference and 0 meaning completely random phase differences. The authoritative introduction to the measurement of the coherence of scalp recorded EEG signals is to be found in Nunez et al. [8-10]

Coherence is a sensitive measure that can reveal subtle aspects of the network dynamics of the brain, which complement the data obtained by the power spectral analyses. Coherence changes can reflect the pathophysiological processes involved in human ageing, but the psychopathology can influence, as well. The age-related EEG desynchrony can be partly explained by the age-related reduction of cortical connectivity. Higher frequencies of oscillations require less cortical area of high coherence. These findings explain why the lowest average coherence values were observed in the beta band, as well as why the beta bands show borderline statistical significance. The age-dependent decrease in coherence may influence the estimation of age-related changes in EEG energy, due to phase cancellation [11-13].

In our previous research we evaluated inter and intrahemispheric EEG coherence in different psychiatric disorders such as: ADHD, anxiety, depression, and Asperger's syndrome (ASP) compared with healthy controls [14].

The aim of this article is to present the obtained results for spectra characteristics and coherence calculation in a group of patients diagnosed as borderline and to compare them with healthy controls. 


\section{METHOD AND SUBJECTS}

The BPD sample comprised 10 patients ( 5 males and 5 females) mean age 20.4 years, selected by chance. Diagnosis was made at the Institute of mental health Belgrade following DMS 5 criteria. Healthy group (HC) also comprised 10 patients (6 males and 4 females) mean age 24.2 years. As can be seen both groups are adequately matched.

QEEG was recorded using a Mitsar 201 (www. mitsar-medical.com), a PC-controlled 19-channel electroencephalographic system. While seated in a comfortable chair, subjects were required to fixate on a computer monitor for a 5 minute period while EEG was recorded with eyes-open condition. All participants were instructed to avoid excessive blinking.

EEG recordings were obtained using an electrode cap (Electro-Cap International) with 19 electrodes placed according to the international 10-20 system, linked ear lobe (A1-A2) referenced and electrode impedance maintained below $5 \mathrm{Kohms}$ for all electrodes. The input signals were filtered between 0.5 and $30 \mathrm{~Hz}$, and digitized at a sampling rate of $256 \mathrm{~Hz}$. Vertical electro-oculogram (VEOG) was recorded with 2 tin electrodes placed $1 \mathrm{~cm}$ above and $1 \mathrm{~cm}$ below the right eye. The cap ground electrode was midway between Fpz and Fz. Quantitative data were obtained using WinEEG software (www. mitsar-medical.com). The linked ears reference montage was changed to average montage prior to data processing. The average montage was used, because it allowed comparisons with the HBI database in WinEEG software. Eye-blink artefacts were corrected by zeroing the activation curves of individual ICA component score responding to eye blinks. In addition, epochs of the filtered electroencephalogram with excessive amplitude $(>100 \mu \mathrm{V})$ and/or excessively fast $(>35 \mu \mathrm{V}$ in $20-35 \mathrm{~Hz}$ band) and slow $(>50 \mu \mathrm{V}$ in $0-1 \mathrm{~Hz}$ band) frequency activities were automatically marked and excluded from further analysis. Finally, EEG was manually inspected to verify artefact removal. A minimum of $90 \mathrm{~s}$ of artefact-free EEG was available for analysis, from which $4 \mathrm{~s}$ epochs were analysed.

Coherence analysis was carried out for the five frequency bands: delta $(0.5-4 \mathrm{~Hz})$, theta $(4-8 \mathrm{~Hz})$, alpha $(8-13 \mathrm{~Hz})$, and beta $1(13-21 \mathrm{~Hz})$ and beta 2 (21-30 Hz). We used these classic fixed frequency ranges to allow our data to be compared with existing coherence data, which has used the stated ranges. Coherence between an electrode pair for a particular frequency band was defined at the cross-spectral power between the sites normalised by dividing by the square root of the product of the power at each site within that band, following Kramer M. (2013).

The WinEEG software allows the mapped computation of 'average coherence' across a range of frequencies across the brain, and gives us a window into 'integration' of function in that range. The EEG coherence is presented by so-called interaction diagrams. Coherence is expressed in numbers from $0-1$, zero being absolutely no relatedness between the signals.

In the WinEEG software programme for EEG coherence, electrodes are connected by curves with different thickness and colours in dependence of value of average coherence: dark blue line - 0.20; turquoise - 0.40; pink - 0.60; red - 0.80 . age 10 .

Statistics was calculated using Statistics pack-

\section{RESULTS}

Demographic characteristics of evaluated samples are presented on Table 1. It is clear that samples are matched by number, gender and age.

Table 1. Demographic characteristics of samples

\begin{tabular}{|l|l|l|}
\hline Diagnosis & Number & $\begin{array}{l}\text { Mean } \\
\text { (vears })\end{array}$ \\
\hline Borderline & $10(5$ males +5 females $)$ & 20.4 \\
\hline Healthy people & $10(5$ males +5 females $)$ & 24.2 \\
\hline
\end{tabular}

Main spectral specifics of borderline compared with control group are presented in Fig. 1. 

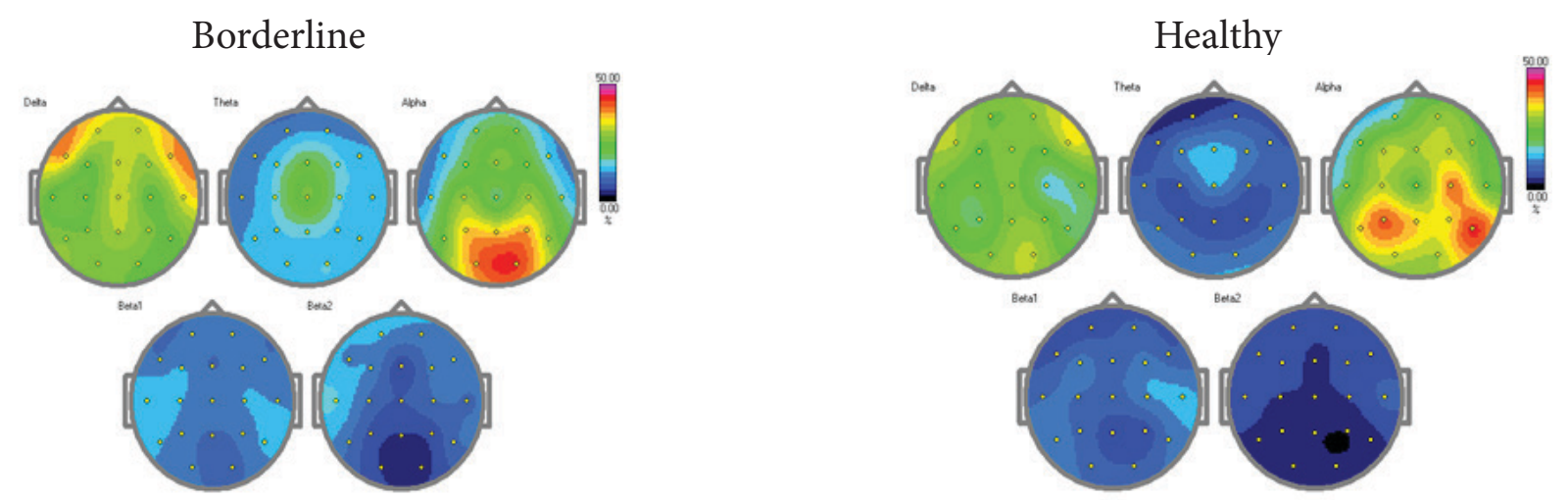

Fig. 1. Spectral characteristics for borderline compared with healthy group

Coherence for all bands in both groups are presented in Fig. 2.
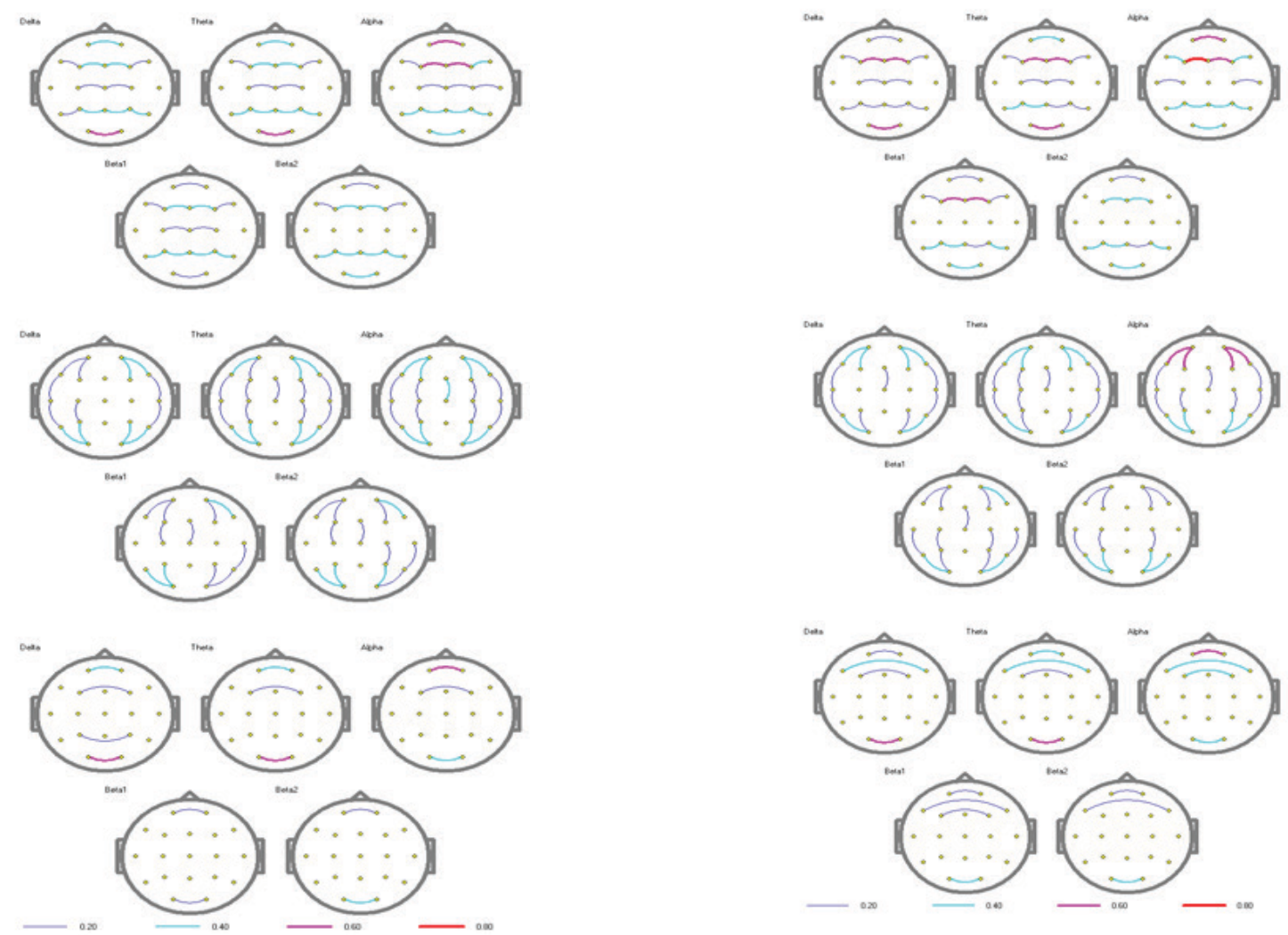

borderline

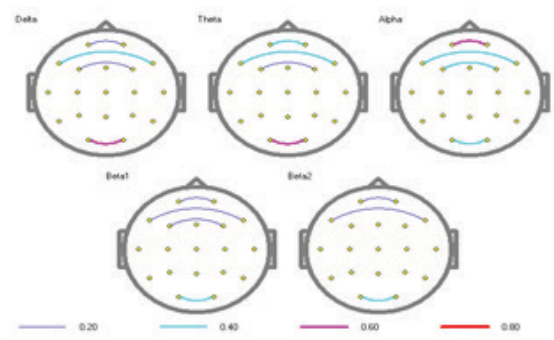

healthy group

Fig. 2. Coherence for all bands in both groups (borderline and healthy)

For all patients data obtained for delta, theta, alpha, beta 1 and beta 2 band are presented separately and compared with healthy group.

For DELTA band, obtained results for relative power are presented in Fig. 3. It is clear that in frontal position no differences are obtained, but in posterior position BPD patients showed higher coherence than healthy group. Additionally, the estimated delta peak frequency is significantly lower for BPD group than HC. 


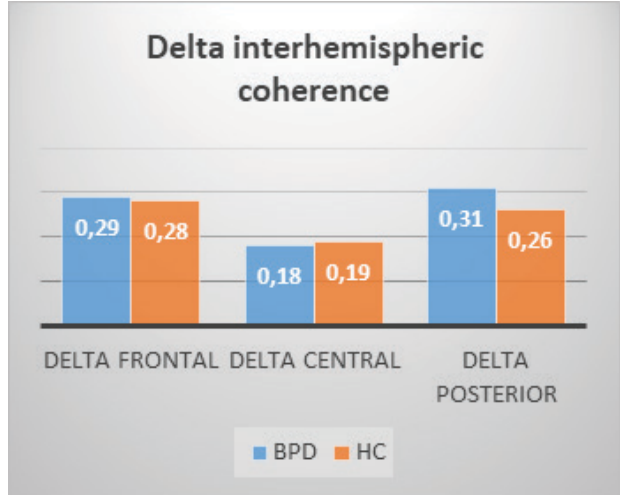

Fig. 3. Delta band coherence characteristics

Separately, frequencies in $\mathrm{Hz}$ calculated for delta band are presented in Fig. 4, showing high statistical difference $(p=0,000)$ between borderline and healthy groups.

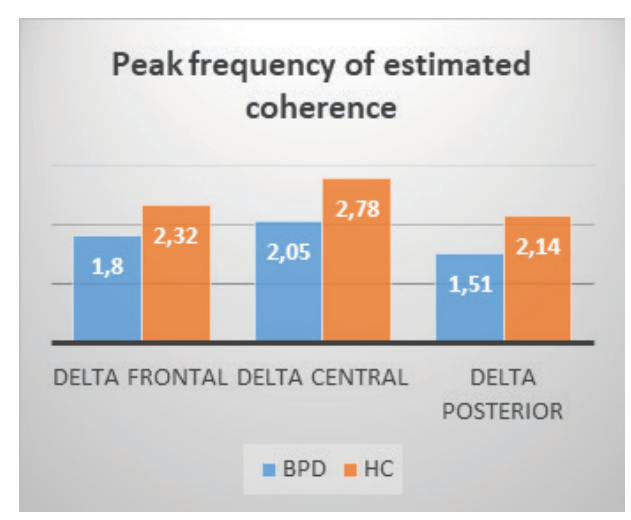

Coherence in delta band showed high statistical significance (Fig. 4)

For THETA band obtained results are presented in Fig. 5 (peak estimated frequency and interhemispheric coherence)

\section{Grupa; LS Means}

Wilks lambda $=, 30079, F(3,16)=12,397, p=, 00019$

Effective hypothesis decomposition Vertical bars denote 0,95 confidence intervals

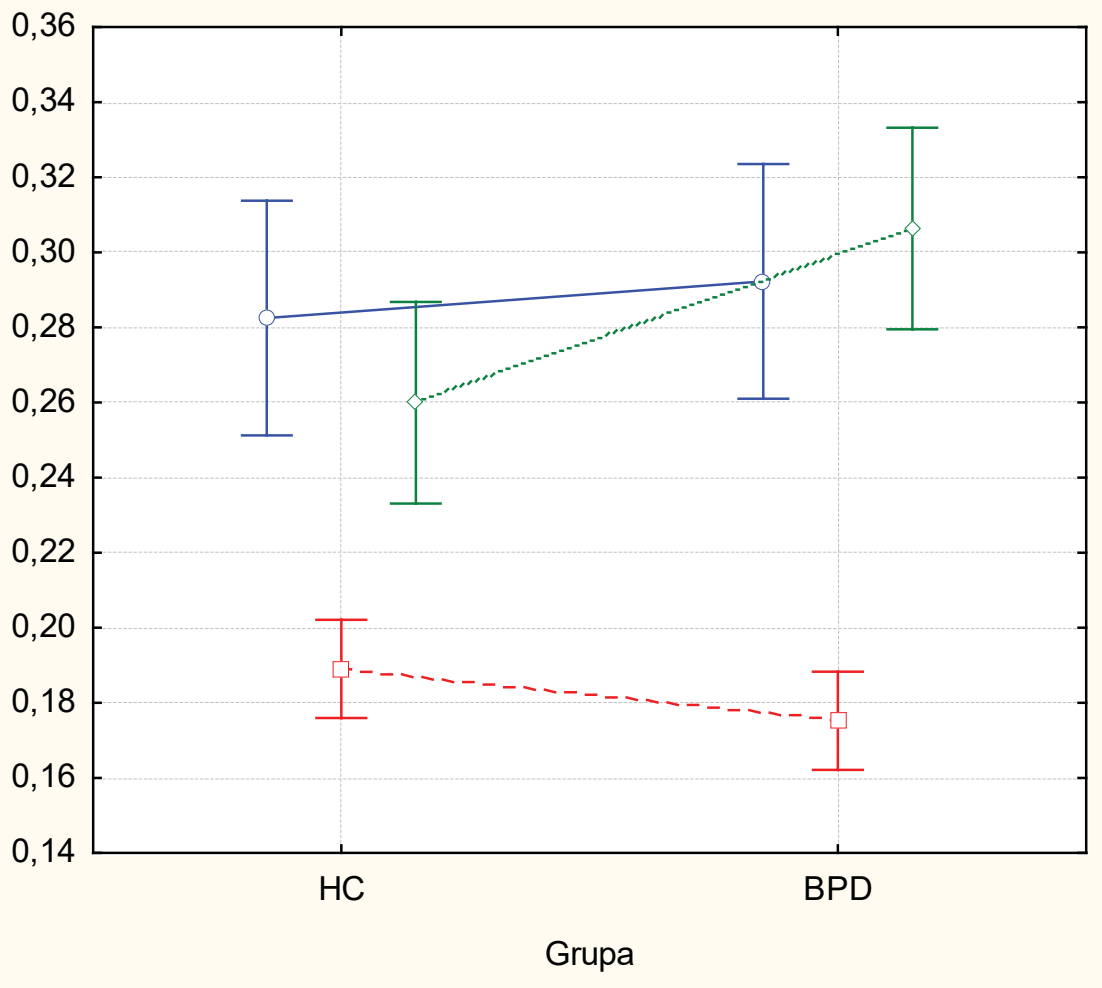

Fig. 4. Coherence calculated for delta band [It is clearly visible significant difference in coherence between groups for delta band] 


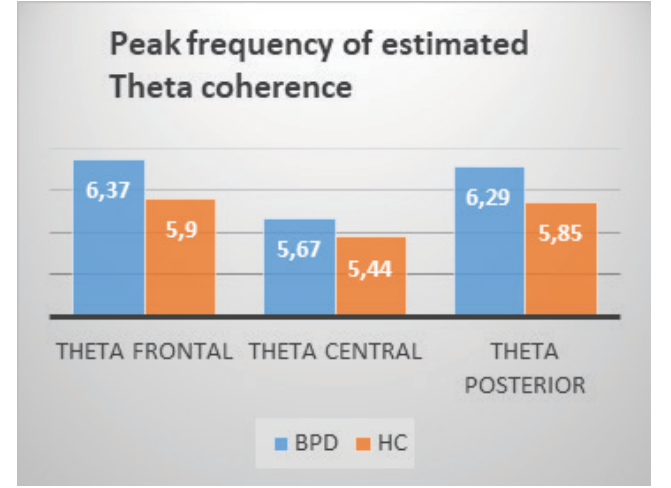

Fig. 5. Theta band coherence characteristics

Coherence for theta band is presented separately in Fig. 6 showing high statistical significance.

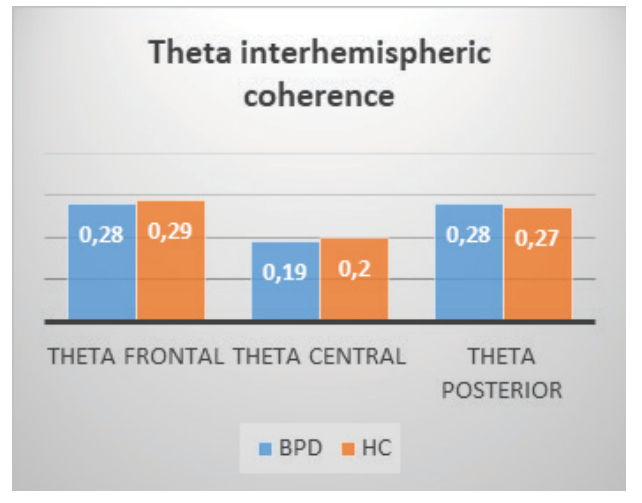

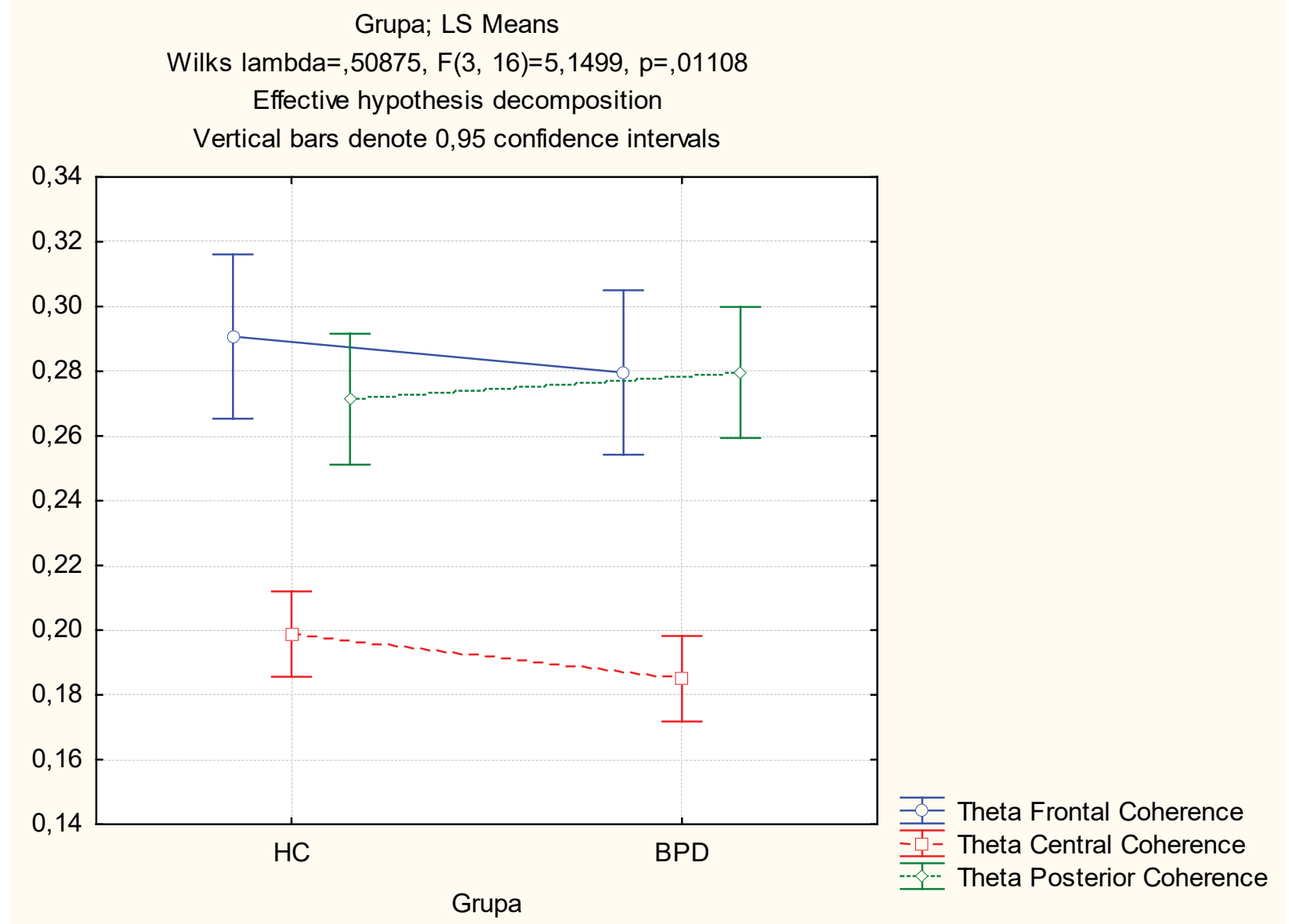

Fig. 6. Coherence for theta band in Fig. 7.

ALPHA band characteristics are presented 

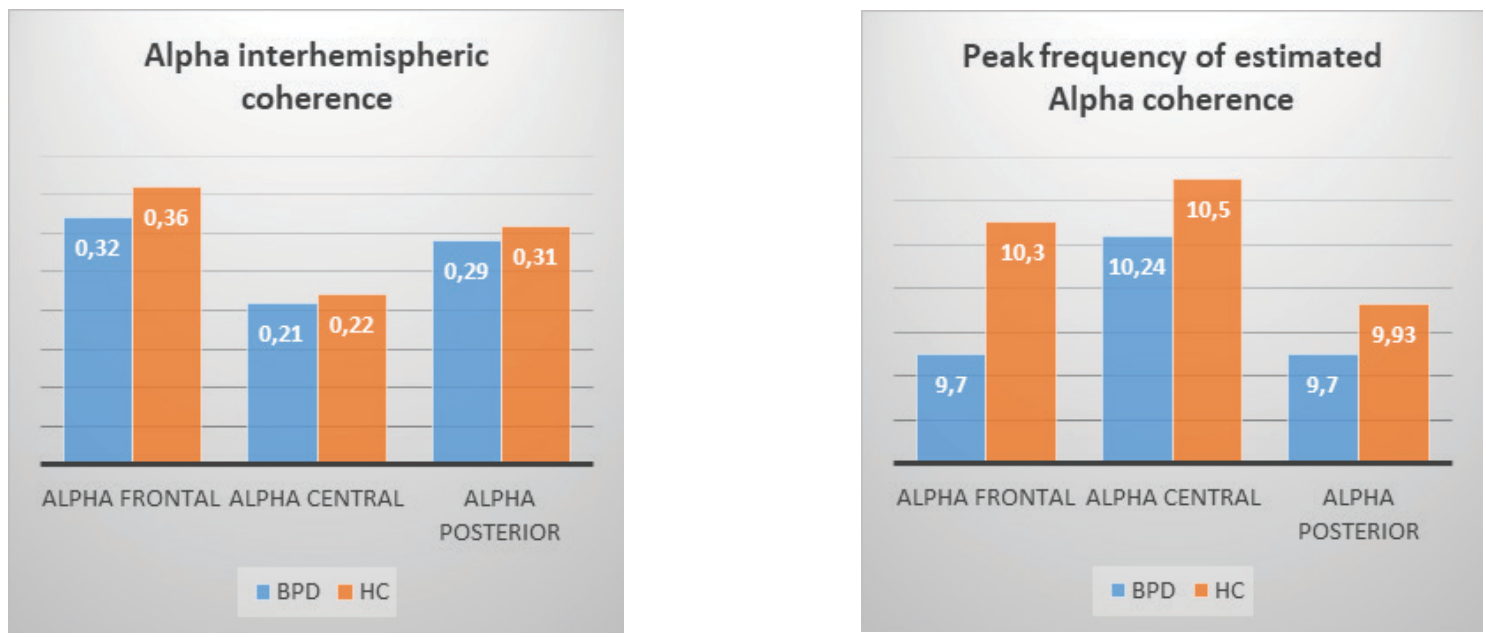

Fig. 7. Characteristics for coherence in alpha band

Calculation for coherence in alpha band showed no significant differences between groups (Fig. 8).

\section{Grupa; LS Means}

Wilks lambda $=, 71905, F(3,16)=2,0839, p=, 14267$

Effective hypothesis decomposition

Vertical bars denote 0,95 confidence intervals

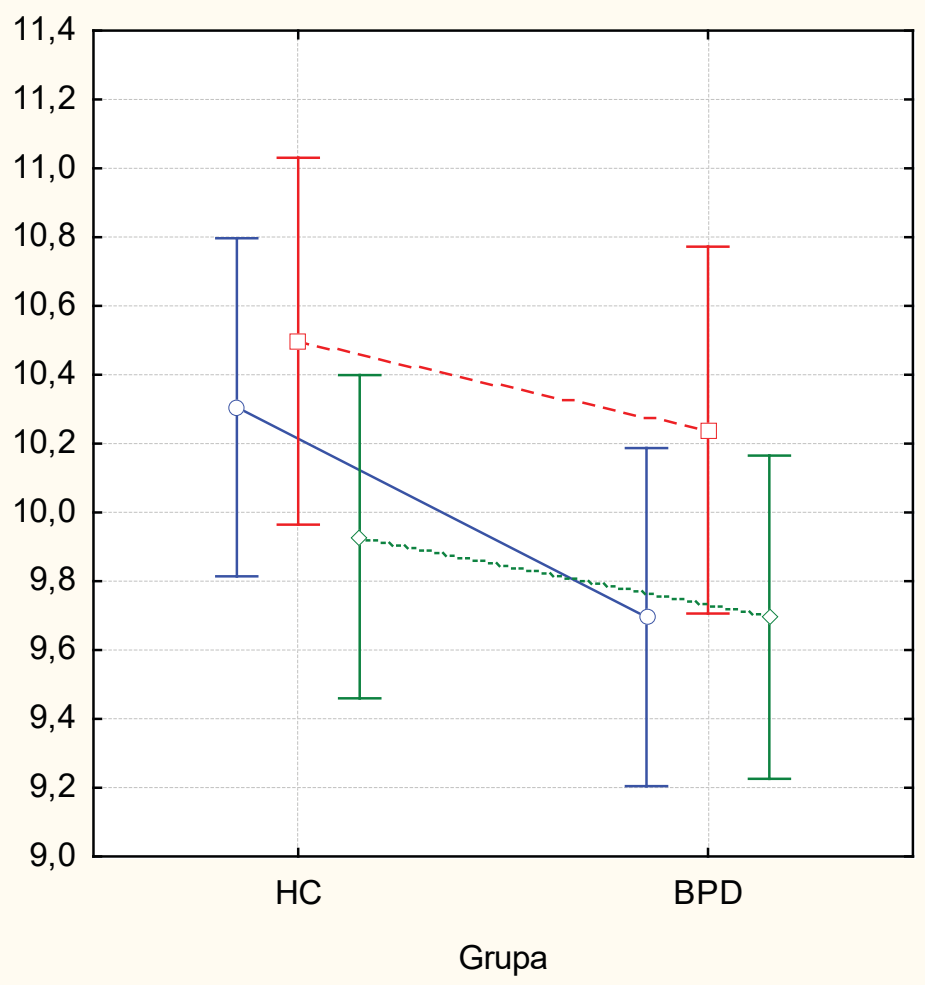

Fig. 8. Coherence for alpha band Fig. 9.

BETA 1 characteristics are presented in 

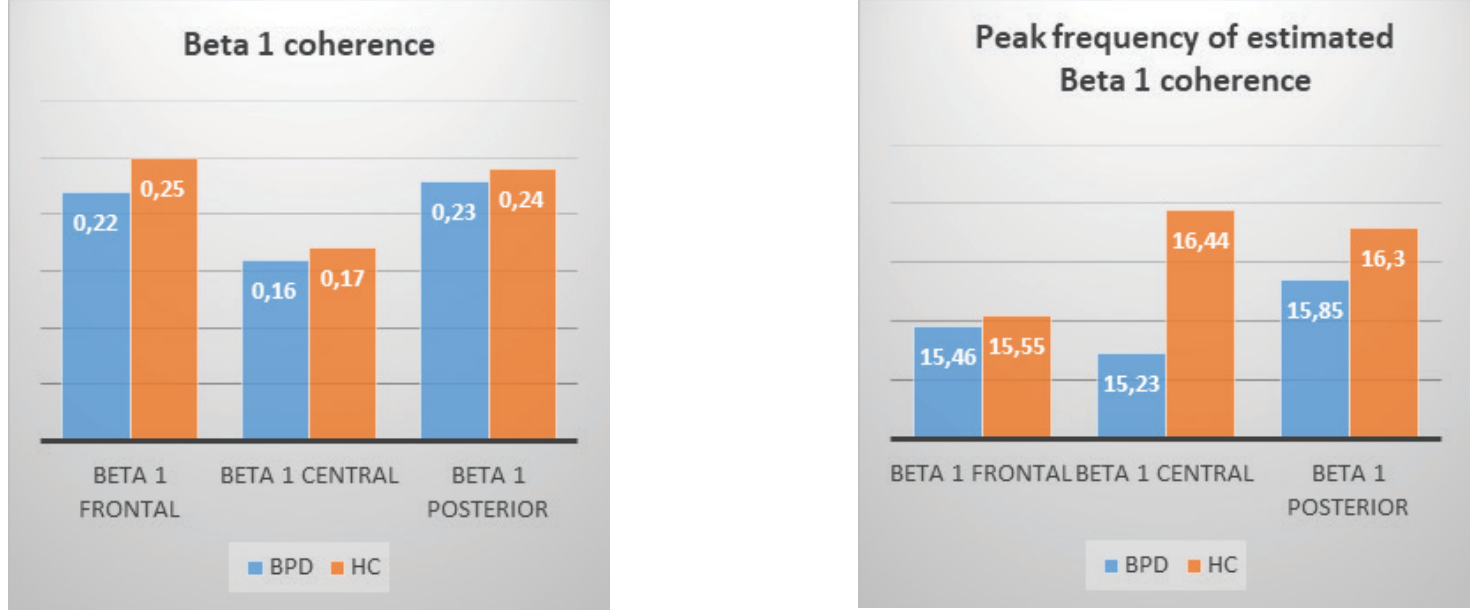

Fig. 9. Beta 1 characteristics

Grupa; LS Means

Wilks lambda $=, 89256, F(3,16)=, 64202, p=, 59907$

Effective hypothesis decomposition

Vertical bars denote 0,95 confidence intervals

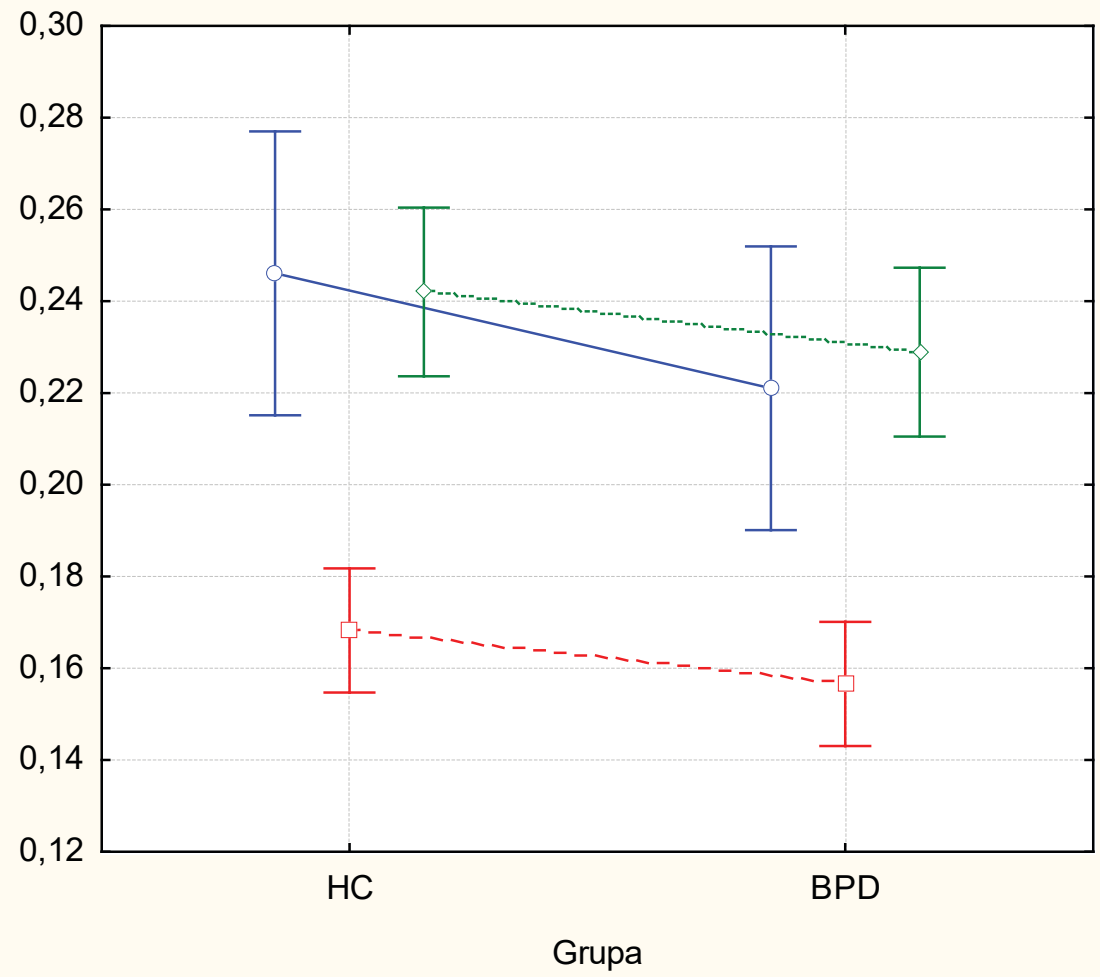

Fig. 10. Coherence for beta band (no statistical significance)

BETA 2 characteristics are presented in Fig. 11. 

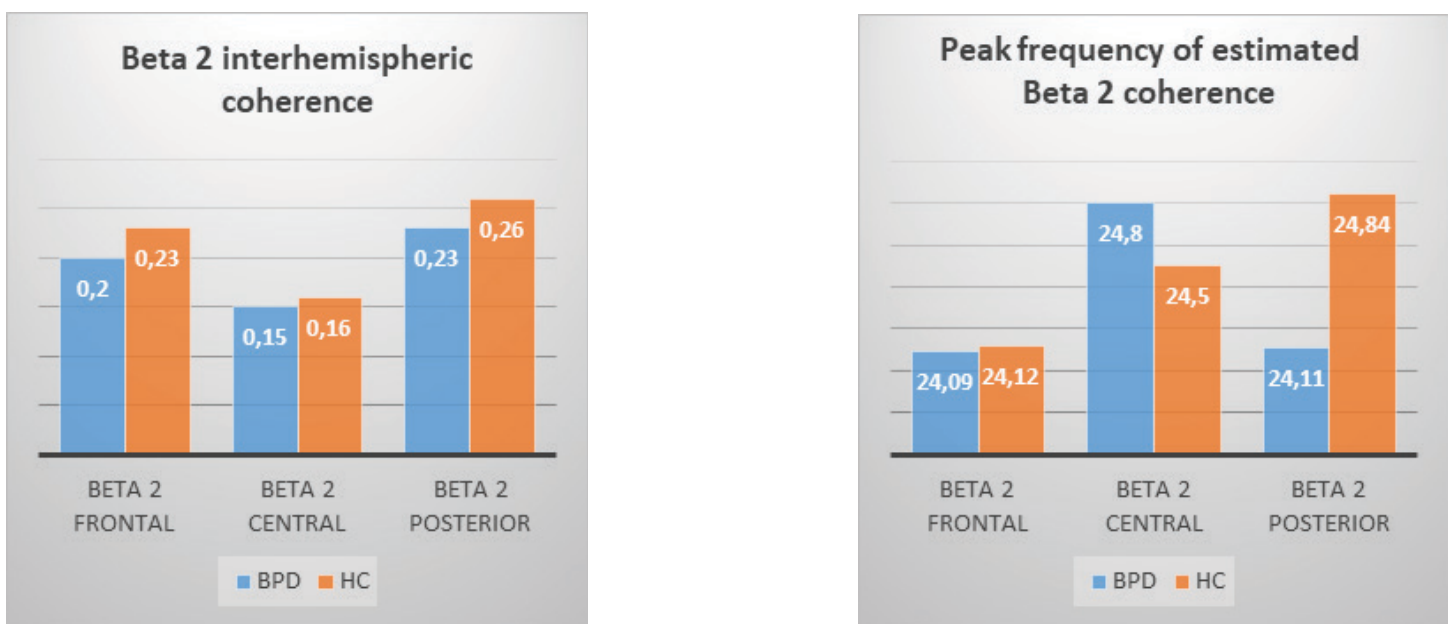

Fig. 11. Characteristics for Beta 2 band

Grupa; LS Means

Wilks lambda $=, 81751, F(3,16)=1,1905, p=, 34483$

Effective hypothesis decomposition

Vertical bars denote 0,95 confidence intervals

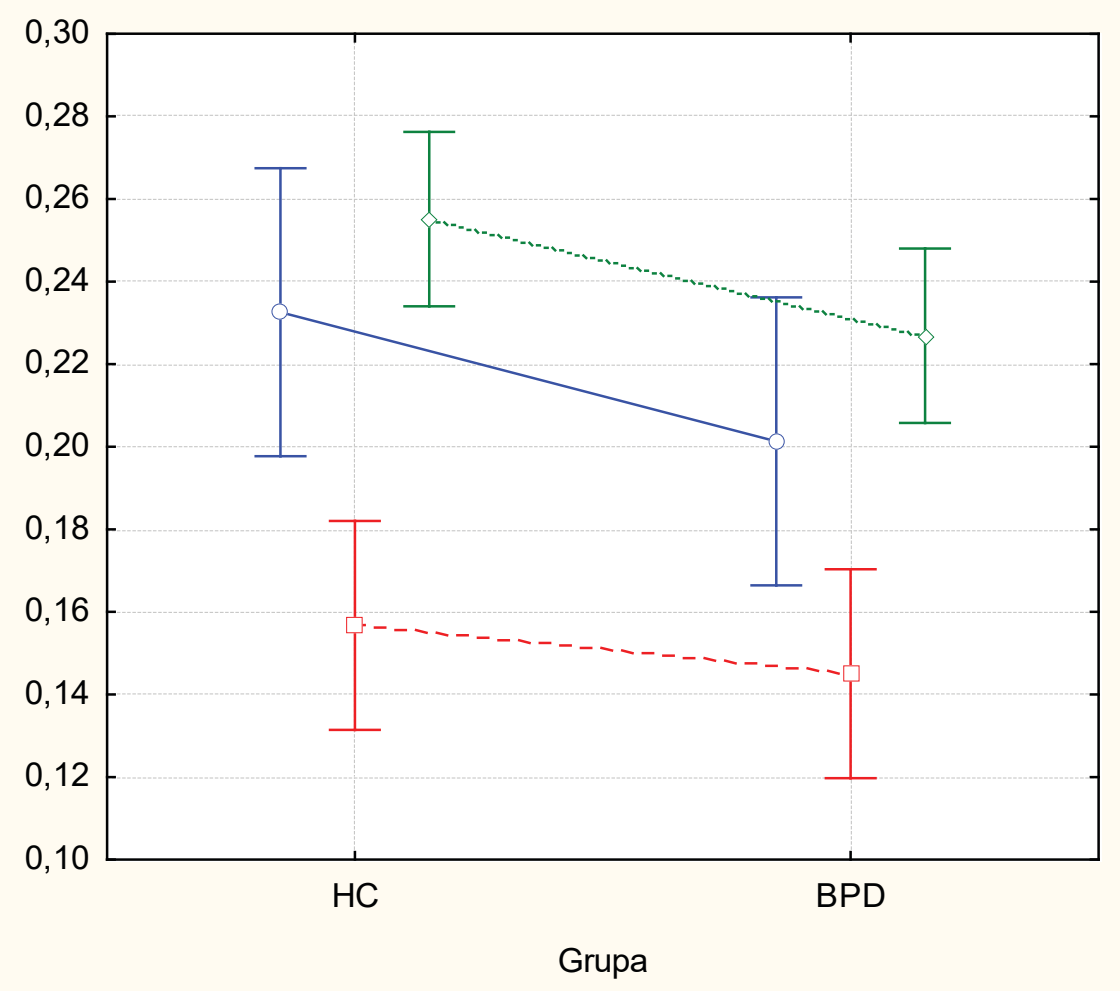

Fig. 12. Coherence for beta 2 band (no statistical significance) 
While doing this study we realized that there are very few papers dedicated to EEG coherence in adults. Practically, there are not published studies for coherence in borderline patients on PubMed. So, it seems that our study is maybe the first one.

Saunders et al. (2016) revealed decreased coherence in the frontal lobe networks in those with autistic spectrum disorder compared to neurotypical controls. This is consistent with other EEG spectra and fMRI research suggesting that neural connectivity anomalies are a major deficit leading to autistic symptomatology.

In our previous research we showed that all evaluated groups (especially ASD, anxiety and depression group) showed lower inter-hemispheric coherence for delta band. Our results for intra-hemispheric coherence have shown that there was significantly lower coherence in both conditions for delta and theta bands in almost all sites for Asperger's syndrome patients. ADHD patients express lower delta inter-hemispheric coherence in frontal regions, and increase coherence of theta in central regions, while increased delta coherence in posterior regions only in EO condition. For depressive and anxious patients we found decreased intra-hemispheric coherence for EO condition for delta brain waves all over the cortex. Generally, main conclusions are related to coherence in low bands (delta and theta).

This study evaluated characteristics of spectra and especially coherence for borderline patients compared with randomly selected healthy people.

We obtained minimal differences in spectra for borderline, but without statistical significance. However, the main characteristics are higher presence of slow bands (delta and theta) in spectra for borderline group.

Concerning coherence, significant differences are obtained for delta ant theta band, but not in alpha, beta 1 and beta 2 band. It can be interpreted that electrophysiological characteristics of borderline patients are fairly normal.

Assessment of coherence was done in patients with Parkinson disease [17].The highest thalamocortical coherence was found in the theta frequency band $(4-9 \mathrm{~Hz})$ with a mean peak frequency of $7.5 \mathrm{~Hz}$.

Luyten P et al. (2005) published relationship between intelligence and coherence. The strongest correlations to IQ were short EEG phase delays in the frontal lobes and long phase delays in the posterior cortical regions, reduced coherence and increased absolute power.

In a study of Cohen, a theory of autistic disorders that has neural connectivity disturbances at its core is presented. Multivariate EEG connectivity indices are utilized to formulate a typology of connectivity anomalies or patterns that have been observed over a series of autistic patients. These represent phenotypic expressions of the underlying pathology that leads to autistic symptoms. Examples demonstrate how these connectivity metrics can be used to understand autistic disturbances and formulate neurofeedback strategies for remedying these difficulties [19].

However, we could not find any article dedicated to coherence in borderline patients. We suggest to evaluate more patients with borderline for more precise results.

\section{CONCLUSION}

- Borderline personality disorder is a clinically important psychiatric disorder that is distinct from major depressive, bipolar and posttraumatic stress disorders, despite overlapping symptoms.

- Symptoms of borderline personality disorder mainly manifest in problems in affectivity, interpersonal functioning, impulse control and cognition.

- Borderline personality disorder can be distinguished from other disorders if a number of these symptoms occur together.

- Electrophysiological characteristics for borderline are fairly without statistical differences except in low bands (delta and theta) which showed lower coherence

\section{Acknowledgement}

The study is a result of joint research between MANU and SANU. We thanks all participants.

\section{REFERENCES}

1. Widiger TA, Weissman MM. Epidemiology of borderline personality disorder. Hosp Community Psychiatry 1991; 42: 1015-21. 
2. Stern A. Psychoanalytic Investigation of and therapy in the border line group of neuroses. Psychoanal Q 1938; 7: 467-89.

3. American Psychiatric Association. Diagnostic and statistical manual of mental disorders, 5th Edition: DSM-5. Washington D. C.: Author (2013).

4. Biskin R, Paris J. Diagnosing borderline personality disorder. CMAJ. 2012 Nov 6; 184(16): 1789-1794.

5. Lind M, Vanwoerden S, Penner F, Sharp C. Inpatient adolescents with borderline personality disorder features: Identity diffusion and narrative incoherence. Personal Disord. 2019 Apr 29. doi: 10.1037/per0000338. [Epub ahead of print]

6. Kerr IB, Finlayson-Short L, McCutcheon LK, Beard H, Chanen AM. The 'Self' and Borderline Personality Disorder: Conceptual and Clinical Considerations. Psychopathology. 2015; 48(5): 339-48. doi: 10.1159/000438827. Epub 2015 Sep 9.

7. Sarah 1. Tragesser, Marika Solhan, Whitney c. Brown, Rachel 1. Tomko, Courtney Bagge, and Timothy j. Trull, Longitudinal associations in borderline personality disorder features: diagnostic interview for borderlines - revised (dib-r) scores over time. J Pers Disord. 2010 jun; 24(3): 377-391.

8. (Nunez, P. Neocortical dynamics and human EEG rhythms. Oxford University Press, New York (1995).

9. Nunez et al. (1997). Nunez PL, Srinivasan R, Westdorp AF, Wijesinghe RS, Tucker DM, Silberstein RB, Cadusch PJ. EEG coherency. I: statistics, reference electrode, volume conduction, Laplacians, cortical imaging, and interpretation at multiple scales. Electroencephalogr Clin Neurophysiol, 1997; 103: 499-515.

10. Nunez PL, Silberstein RB, Shi Z, Carpenter MR, Srinvasan R, Tucker DM, Doran SM, Cadusch PJ, Wijesinghe RS: EEG Coherency II: Experimental comparisons of multiple measures. Clin Neurophysiol 1999; 110: 469-486.
11. Vysata O, Kukal J, Prochazka A, Pazdera L, Simko J, Valis M. Age-related changes in EEG coherence. Neurol Neurochir Pol. 2014 Jan-Feb; 48(1): 3 5-8. doi: 10.1016/j.pjnns.2013.09.001. Epub 2014 Jan 23.

12. Duffy FH, Jones KH, McAnulty GB, Albert MS: Spectral coherence in normal adults: unrestricted principal components analysis - relation of factors to age, gender, and neuropsychologic data. Clin Electroencephalogr 1995, 26: 30-46.

13. Robert Thatcher, D North, C Biver. Mechanism and significance of global coherence in scalp EEG. Current Opinion in Neurobiology, 2014; 31C: 199-205.

14. Silvana Markovska-Simoska, Nada Pop-Jordanova, Jordan Pop-Jordanov. EEG inter and intra-hemispheric coherence study in adults with psychiatric disorders CONTRIBUTIONS. Sec. of Med. Sci., XXXIX 2-3, 2018: 5-19.

15. Mark A. Kramer, An Introduction to Field Analysis Techniques: The Power Spectrum and Coherence, Kramer, 2013 Department of Mathematics and Statistics Boston University Boston, Massachusetts, MATLAB.

16. Saunders et al. (2016) Saunders, A. Kirk, I. J. and Waldie, K. E. (2016). Hemispheric Coherence in ASD with and without Comorbid ADHD and Anxiety, BioMed Research International, vol. 2016, Article ID 4267842, 12 pages, 2016.

17. Sarnthein J., Daniel Jeanmonod D. High Thalamocortical Theta Coherence in Patients with Parkinson's disease. Journal of Neuroscience 3 January 2007; 27 (1): 124-131.

18. Luyten P, Campbell C, Fonagy P. EEG and intelligence: Relations between EEG coherence, EEG phase delay and power. Clinical Neurophysiology, 2005; 116(9): 2129-41.

19. Coben, R., and Myers, T. Connectivity theory of autism: use of connectivity measure in assessing and treating autistic disorders. J. Neurother. 2008; 12: 161-179. doi: 10.1080/10874200802398824 


\title{
Резиме
}

АНАЛИЗА НА ЕЛЕКТРОЕНЦАФАЛОГРАФСКИТЕ КАРАКТЕРИСТИКИ И КОХЕРЕНЦИЈАТА КАЈ ПАЦИЕНТИ СО ГРАНИЧНО РАСТРОЈСТВО

\author{
Нада Поп-Јорданова ${ }^{1}$, Силвана Симоска-Марковска', \\ Маја Миловановиќ ${ }^{2}$, Душица Лечиќ-Тошевски ${ }^{2}$ \\ ${ }^{1}$ Македонска академија на науките и уметностите, Скопје, Северна Македонија \\ ${ }^{2}$ Институт за ментално здравје, Белград, Србија
}

Граничните личностите претставуваат важна психијатриска дијагноза, различна од оние со мајорна депресија, биполарно или посттравматско стресно растројство, иако имаат заеднички симптоми. Дијагнозата се поставува главно клинички, според карактеристиките содржани во ДМС 5 (или ИЦД 10).

Најчестата возраст на прва појава на симптомите е доцната адолесценција, но дијагнозата многу често може да биде погрешна.

Нашата студија се однесува на карактеристиките на квантитативна електроенцефалографија, како и кохеренцијата кај граничните пациените, споредено со група здрави субјекти, кои соодветствуваат по возраст, број и пол, а се селектирани по случаен избор.

Добиените резултати покажаа дека електроенцефалографските карактеристики за граничните болни се, практично, без особени статистички разлики, но со позначајна застапеност и кохеренција на бавните бранови (делта и тета) кај болните во споредба со здравите испитаници. Се препорачува истражување на поголема група испитаници од истово растројство.

Клучни зборови: гранична личност, кохеренција, електроенцефалографија 